\title{
IAMJ
}

INTERNATIONAL

AYURVEDIC

MEDICAL JOURNAL

\section{IMPORTANCE OF AHAR AND AGNI IN MAINTENANCE FOR HEALTHY LIFE}

\author{
Priti Pragat Gahukar ${ }^{1}$, Vedprakash Gahukar ${ }^{2}$ \\ ${ }^{1}$ Assistant Professor in Jupiter Ayurveda Medical College, Nagpur, Maharashtra, India \\ Academic Head, Med Ayu Hospital, Nagpur, Maharashtra, India; \\ ${ }^{2}$ BAMS MD, Ayurveda \& Lifestyle Consultant, \\ Director Med Ayu Hospital, Maharashtra, India
}

Corresponding Author: pvgahukar17@gmail.com

https://doi.org/10.46607/iamj5009092021

(Published Online: September 2021)

Open Access

(C) International Ayurvedic Medical Journal, India 2021

Article Received: 08/09//2021 - Peer Reviewed: 15/09/2021 - Accepted for Publication: 16/09/2021

\section{Check for updates}

\begin{abstract}
The body is the outcome of food. Even so, the disease is the outcome of food. The distinction between ease and disease arises on account of wholesome nutrition or the lack of it respectively. Food is the factor that sustains and supports the Deha Dhatus, Ojas, Bala and Varna. Ayurved is mainly based on preventive aspects first than curative. Food is considered as the first pillar among the Nidra(Sleep) and Brahmacharya being the other two. Food is important as a nutritional source, also with therapeutic value. It also plays a very important role during the posttreatment period in regaining the diminished strength due to the harmful effect of the disease. Ayurveda gives immense importance to Pathya Ahar in the words" without the use of Pathyakar Ahar medicines is of no use and if Pathyakar Ahar is taken there is no need of other medicines." This food depends upon Agni to contribute to the nourishment of the body. The body elements or Sharira Dhatus cannot be nourished and developed when food is not properly digested by Agni. Ayurveda considers Dehagni as a cause of life, complexion, strength, health, lustre, Oja, Teja, nourishment and Prana. As per Acharya Charak, Agni is divided into 13 types i.e. one Jatharagni, five Bhutagni and seven Dhatvagni. Jatharagni (Digestive power) is directly related to Dhatvagni or bioenergy in the cells and their metabolic processes, with ultimate tissue metabolism or Dhatu Nirmana Processes. All the
\end{abstract}


normal functions of Dhatu, Upadhatu and Mala in the body all are directly dependent on the health status of Agni. Thus, Pathyakar Ahar and Agni play an important role in the maintenance of healthy life.

Keywords: Ahar, Agni, Jatharagnii, Hair, Kesha

\section{INTRODUCTION}

The body is the outcome of food. Even so, the disease is the outcome of food. The distinction between ease and disease arises on account of wholesome nutrition or the lack of it respectively. Food is the factor that sustains and supports the Deha Dhatus i.e. tissue element, Ojas i.e. the factor of resistance to disease and decay, Bala i.e. strength or capacity to perform Physical work and complexion among others. This food depends upon Agni to contribute to the nourishment of the body. The body elements or Sharira Dhatus (Body tissue) cannot be nourished and developed when food is not properly digested by Agni.

The Sanskrit "Agni" represents the fire element responsible for generating heat and chemical energy in the body. Agni has been described as the one who carries everything, moves everywhere, which can metamorphoses substances, which can bring transformation in substances, assimilates, which gives and takes, which can enter into minute channels, which burns, which glows etc. ${ }^{1}$ Agni is a key factor in the transformation of consumed Ahara Viharadi dravyas of Vijatiya origin to Sajatiya nature, Agni is derivative of Tejas Mahabhuta, and it carries metabolic transformations in which the inherent feature changes.

Ingested food is to be digested, absorbed, and assimilated, which is inevitable for the preservation of life, and is performed by the Agni. In Ayurveda, the term "Agni" is used in the logic of digestion of food and metabolic products. As per Acharya Charak according to the various functions and place of action Agni is divided into 13 types i.e. one Jatharagni, five Bhutagni and seven Dhatvagni. According to Acharya Sushruta, five types of Agnis are illustrated, viz. Pachakagni, Ranjakagni, Alochakagni, Sadhakagni and Bhrajakagni. Agni renovates food in the form of energy, sugar which is accountable for all the vital functions of our body. Acharya Charak has mentioned that after slowdown or stoppage of the function of Agni, the individual dies, and when the Agni of an individual is Sama, then that person would be healthy and would lead a happy, healthy lengthy life. Therefore, Ayurveda considers that Dehagni is the cause of life, complexion, strength, health, lusture, Oja, Teja (energy), nourishment, prana (life energy). Jatharag$n i$ is directly related to Dhatvagni or bioenergy in the cells and their metabolic processes, with ultimate tissue metabolism or the Dhatu-Paka process. Jatharagni is considered to be the most important because every nutrient that one ingests first comes to the Jathara and is subjected to the action of Jatharagni. All the Dhatvagni depend on the normal, healthy state of Jatharagni. Therefore, in Ayurveda, the concept of Agni, its importance in Ahar, it's Dushikar Hetu and its Chikitsa provides an extensive field of research in the present day.

\section{Aim and Objectives:}

1. To study and discuss the concept of Ahar for maintenance of healthy life

2. To study and discuss the concept of Agni for maintenance of healthy life

\section{Material and Methods:}

This article is a review of various Ayurvedic classical texts. Materials related to Ahar, Agni and its importance for the maintenance of life in Ayurveda and other related topics have been collected from various Ayurvedic classical texts. The references were compiled, analyzed and discussed for a thorough understanding of the concept of Ahar and Agni and its importance for a healthy life. The Samhitas used in the present study were Charak Samhita, Sushruta Samhita and Ashtanga Hrudaya with commentaries on them.

Concept of Ahar: The Ayurvedic diet pattern is an eating pattern that's been around for thousands of years. It's based on the principles of Ayurvedic Sid- 
dhanta and focuses on balancing Tridosha within the body, which is said to improve health. Food is the factor that sustains and supports the Deha Dhatus i.e. tissue element, Ojas i.e. the factor of resistance to disease and decay, Bala i.e. strength or capacity to perform Physical work and complexion among others. Agni is also dependent on the quantity and quality of diet taking. Satva i.e. Manas Bhav also gets energy from Ahar. Various types of Ahar gets digested with different types of Agni and gets transferred into Sharir Dhatu. Our life is dependent on Ahar. Ahar is the ultimate cause of Shubha Ashubha Bhav in the body. The body gets nourished by the healthy Ahar and gets diseased by the unhealthy Ahar. It means that it is one of the important causes of healthy or unhealthy life. Diet should be Matravat i.e. in proper quantity. It should not be more or less. Quantity of diet should be dependent o one digestive capacity i.e. Agni. Amatravat Ahar (diet in less quantity) is said to be Anayushyakar i.e. dangerous for life. Atimatravat Ahar (diet in more quantity) is responsible for Tridosha Prakopa which is a cause of disease and ultimately Dukhayu (Painful life). Diet should be changed according to seasonal change, which is termed Rutusatmya Ahar. It is responsible for Bala, Varna and Sukhayu (happy life). Ahar should be Hitahar (Pathyakar) which is beneficial for the body in the long term. Ahitakar Ahar is responsible for various disorders in the body. Ahar should be Shadrasatmak (with all the six tastes). Excess intake of any one of the tastes will cause disease. Therefore, the use of all six Rasa should be Practiced in the diet, not a specific one. The person who practices all the tastes and Ghruta Kshir, etc. hitakar Ahar, will be always Balawan (strong) and Dirghayushi (long life). And the person, who practices Ruksha Ahar and only one taste, will always be Alpa Bala and Alpayush (short life). Ahar should not be Viruddha means opposite to properties of Body. It can cause various disorders like Kushtha, Kilas and Grahani, etc.

One should take diet with consideration of Ashtaaharvidhi Visheshayatan and Ahar Vidhi Vidhan, it will ultimately be responsible for long life.
Concept of Agni: - An almost complete account of the process of digestion and metabolism of food as understood and explained by Ayurveda is seen described by Chakrapani Datta, in this commentary on chapters entitled Vividhashitapitita in the Sutrasthana and Grahani chikitsa in Chikitsa sthana of Charaka Samhita. A careful and critical study of the original texts in these chapters and the commentary of Chakrapani Datta thereon are revealing and already reached a high degree of development. "Agni of the body, according to Ayurveda is implicit in pitta and "as pitta performs Dahana i.e. oxidation or combustion, Pachana i.e. physical or chemical transformations like fire, it is spoken of as internal fire. The Dahana and Pachana refer to the food, drinks etc., ingested. Confining ourselves to the essentially digestive and metabolic functions of pitta, it is seen that the Pachaka Pitta, located in the Adhoamahaya, splits the different components of food into their respective elemental units i.e. Anus; the five kinds of Bhutagni, at this level, makes the absorption of the end-products of digestion present in the Ahararasa possible; as seven specific pittas (Saptadhatvagnis), it metabolizes and transforms species Prasada/Poshaka/Asthayi Dhatus, on the one hand, and metabolic wastes i.e. Mala on the other; as Bhutagnis, again, in tissues, it initiates physicochemical reactions concerned with the incorporation of the nutrient precursor in the corresponding tissue elements and, as Pachaka pitta, at this level, it completes, energy and synthesis metabolism. The constant destruction of tissues that occurs throughout life, in the Ayurvedic view, is offset by the synthesis of tissues with materials derived from food sources.

While the pitta or Agni organization represents an inbuilt mechanism, both at the level of Shariravaya Paramanus as well as at that of the human organism as a whole-its proper functioning, according to Ayurveda, is stated to be determined by food. Elsewhere Charaka was quoted as stating Bala, Arogya and Ayuh are dependent on Agni. He has proceeded to observe in this passage that "Agni in its turn waxes being fed with Indhana i.e., fuel, in the form of foods and drinks and that, it wanes in its absence" 
In addition, according to him, the food which is the factor that nourishes tissue elements and Ojas i.e., the factor of resistance to disease or immunity and contributes to Bala i.e., capacity to perform work, complexion etc. itself depends upon Agni for its utilization, as Rasadhidhatus (metabolically processed precursor nutrients of tissue elements or Poshaka dhatus) cannot be formed from a food that has not been digested and metabolized.

Moieties or aspects of Kayagni, which latter while being in its place, are contributed to and permeate all the Dhatus. A decrease of Kayagni and the contribution it makes to the Dhatus, makes for an increase of the latter, while an increase makes for a decrease of them.

The concept of Pachaka pitta, as reflected in the citations above, studied together with the citation quoted earlier from Charaka Samhita, that "Koshthagni is the leader of all Agnis" open out many significant and far-reaching possibilities. The life of all living beings is food, and the world seeks food. The complexion, clearness of mind, good voice, longevity, understanding, ease and pleasure, satisfaction, growth, strength, and intelligence are all dependent upon food. It should not be assumed that every substance which is homologous to the tissues of the body will straight away contribute to the growth of corresponding tissues of the body. It must be noted that food substances are drawn from the body. It must be noted that food substances drawn from the environment are all Vijatiya or foreign to the body and they should be suitably processed before they are utilized by and made part and parcel of the Sharira dhatus, that is to say, they must be transformed as Sajatiya or body i.e., tissue-specific substances or, in other words, Dhatwaharas (nutrients specific to each species of Sharira-dhatus viz., Rasa poshaka dhatu, Rakta poshaka dhatu, Mamsa poshaka dhatu, Medo poshaka dhatu, Asthi poshaka dhatu, Majja poshaka dhatu and Shukra Poshaka dhatu. Such a paka i.e. transformation, mutation and transmutation are made possible by Jatharagni, Bhutagni and Dhatwagni. The food, after being transformed by dhatvagnis, as seven kinds of poshaka or asthayi dhatus (i.e., the seven kinds of specific nutrient homologues of the corresponding seven species of basic tissue elements) is transported by Rasadhatu to the remaining poshaka dhatus, through their srotasas, to nourish them.

The foods consumed in different forms viz., drunk fluids, electuaries that are licked and solids that are masticated etc., after being digested and ignited by Antaragni, are again dealt with efficiently by their own Ushma, in a continuous process, throughout the body, without any respite or resting at any point, like the inexorable time, which is always on the move forward. Dhatupaka, under the influence of Dhatushmas, the circulation of the products of this Paka through transport pathways the physiological integrity of which is not impaired, being directed and controlled by normally functioning Vayu, they promote the growth of the body, strength, complexion, health, longevity and the tone of the Dhatus. The nutrient dhatus contribute to the maintenance of the normalcy of the Sharira Dhatus.

Jathragni is said to be the leader of all other Agni. Because Jatharagni supports and stimulates the other types of Agni i.e. If Jatharagni is healthy, it will make other types of Agni healthy. Also, Agni plays an important role in the determination of Matra of diet. The quantity which does not harm after ingestion of food is called the proper quantity of food. The quantity depends on the strength of the digestive fire. Chakrapani says that looking to first, the second and third-degree of digestive fire the quantity of diet is also decided accordingly. If Agni is Tikshna, Ahar should be taken in more quantity. If Agni is Manda, Ahar should be taken in less quantity and if Agni Bala is Madhyam, Ahar should be taken in moderate quantity. The word 'Punah' denotes reveals of the quantity according to variation in the strength of digestive fire because it varies in the individual according to variation of season and Age. For instance, digestive fire is strong in winter and youthful; an age whereas in diet also can't be fixed for ever but it modified according to the present state of digestive fire. Thus, Agni Parikshan is important.

Agni parikshan: - Following are the function status of Agni under various conditions 
1. Tikshnagni: - Agni under the influence of pitta dosha is tikshnagni. Agni is intense and can digest all types of Pathyakar and Apathyakar Ahar.

2. Mandagni: - Agni under the influence of Kapha dosha is mandagni. Agni cannot even digest Pathyakar Ahar, even in a small amount

3. Samagni: - Agni under the influence of equilibrium of Tridosha result of well-balanced Dosha. If Pathyakar Ahar is taken it remains unaffected and if Apathyakar Ahar is taken it gets affected.

4. Vishamagni: - Agni under the influence of Vata dosha is Vishamagni.

Even if Pathyakar Ahar is taken it gets affected and even if Apathyakar ahar is taken it remains unaffected.

One dies if this Agni gets extinguished, lived long free from disorders if it is functioning properly gets ill if it is deranged, Hence Agni is the root cause for all Agni, Bala, Varna etc. The Agni which digests food is regarded as the master of all Agni because the increase and decrease of other Agni depend on the digestive fire. Hence one should maintain it carefully by taking properly the wholesome full of food and drinks because on its maintenance depends on the maintenance of lifespan and strength. Agni is stabilized by the application of unctuous food. For Agni pravartan, Ahar should be Hitakar Jirna and Matravat.

\section{DISCUSSION}

Food is the factor that sustains and supports the Deha Dhatus, Ojas, Bala and Varna. Ayurved is mainly based on preventive aspects first than curative. Food is considered as the first pillar among the Nidra and Bramhacharya being the other two. Food is important as a nutritional source, also with therapeutic value. It also plays a very important role during the posttreatment period in regaining the diminished strength due to the harmful effect of the disease. Diet should be Rutusatmya changed according to seasonal change, Pathyakar, Shadrasatmak but should not be Viruddha. One should take diet with consideration of Ashtaaharvidhi Visheshayatan and Ahar Vidhi Vidhan, it will ultimately be responsible for long life.
Diet should be Matravat, and quantity of diet is dependent on Agni. Agni is a variable factor. So, Agni Parikshan should be done frequently, and the quantity of diet should be changed accordingly. Agni Viruddha diet can be responsible for various disorders in the body. So Ahar and Agni both play an important role in the maintenance of healthy life.

\section{CONCLUSION}

Agni plays an important role in maintaining health of body, the functioning of the body, the body's metabolism and the proper functioning of the body. In Ayurveda, Agni correlates with the digestive power of the body. There are many reasons for maintaining agni (digestive power of the body). Bhutagni and Dhatvagni (metabolism at the cellular level). They work together to maintain balance in the body as Jhataragni maintains metabolism and Bhutagni and Dhatuagni maintain cell metabolism. The imbalance in the physiology of Agni is the main cause of the formation of $A m a$, which is the main cause of many diseases. So, in order to treat any disease, the concept of Agni should be taken care of during management.

\section{REFERENCES}

1. Bhattacharya, Taranath Tarkavachaspat. editor, Vachaspatyam: Edition: 4th ed.a comprehensive sanskrit dictionary, Vol.3 Publisher: Varanaasi : Chowkhamba Sanskrit Series Office, 1990

2. Agnivesa's Charakasamhita, Cikitsa Sthana 15/13, text with English translation by R. k. Sharma and Bhagavandas volume III, Published by Chowkhamba Sanskrit Series, Varanasi. 2009.p.

3. Agnivesa's Charakasamhita Cikitsa Sthana 15/14, text with English translation by R. k. Sharma and Bhagavandas volume III, Published by Chowkhamba Sanskrit Series, Varanasi. 2009

4. Susruta Samhita Sutra sthanam with English Translation of text and Dalhana's commentary along with critical notes. 21/5, Vol. I, Edited \& translated by Pria Vrat Sharma, Chowkhamba Visvabharati Oriental Publisher \& Distributors, Varanasi. 2001

5. Susruta Samhita Sutra sthanam with English Translation of text and Dalhana's commentary along with critical notes. 21/9, Vol. I, Edited \& translated by Pria 
Vrat Sharma, Chowkhamba Visvabharati Oriental Publisher \& Distributors, Varanasi. 2001

6. Agnivesa's Charakasamhita Sutra Sthana 12/11, text with English translation by R.k. Sharma and Bhagavandas volume III, Published by Chowkhamba Sanskrit Series, Varanasi. 2009

7. Agnivesa's Charakasamhita Cikitsa Sthana 28/6, 15/6-8, text with English translation by R.k. Sharma and Bhagavandas volume III, Published by Chowkhamba Sanskrit Series, Varanasi. 2009

8. Vd. Dash Bhagwan, Concept of Agni in Ayurveda with Special Reference to Agnibala Pariksha. Varanasi: Chaukhambha Amarabharati Prakashan; 2nd. 1993.p.78

9. Dwarkanath C. Digestion and Metabolism in Ayurveda. Varanasi: Krishnadas Academy, 2nd. 1997; p.59

10. Dr Goverdhan Vani, J.S.R.A. Prasad, International Ayurvedic Medical Journal; Concept of Agni and Ahar Paka (metabolic transformation) in Ayurveda.2010, p. 145

\section{Source of Support: Nil \\ Conflict of Interest: None Declared}

How to cite this URL: Priti Pragat Gahukar \& Vedprakash Gahukar: Importance Of Ahar And Agni In Maintenance For Healthy Life. International Ayurvedic Medical Journal \{online\} 2021 \{cited September 2021\} Available from: http://www.iamj.in/posts/images/upload/2247_2252.pdf 